\title{
GAMBARAN PENGETAHUAN IBU TERKAIT MAKANAN SEHAT DAN GIZI BAGI BAYI USIA 0- 12 BULAN
}

\author{
Riska Arsita Harnawati \\ Diploma III Kebidanan, Politeknik Harapan Bersama Tegal \\ Email: riskaarsita23@gmail.com
}

\begin{abstract}
Abstrak
Pentingnya ibu mengetahui tentang nutrisi dan gizi yang tepat dan sehat untuk bayi dengan usia 0-12 bulan yaitu agar status gizi baik, sehingga tumbuh kembang bayi akan sesuai dengan umurnya. Penelitian ini bertujuan melihat deskripsi terkait pemahaman ibu berkaitan dengan kebutuhan makanan, nutrisi, dan gizi bagi bayi usia 0-12 bulan. Metode penelitian yang digunakan adalah survey deskriptif, dengan jumlah sampel yang di gunakan adalah 52 responden. Cara pengambilan sampel yaitu dengan membagi kuesioner yang dbagikan kepada ibu yang mempunyai bayi dengan usia penelitian. Hasil yang didapatkan, ibu yang memiliki pengetahuan baik sekitar 35 responden (67,3\%), karakteristik responden berdasarkan umur 7 responden (100\%), pendidikan 17 responden (77,2\%),pekerjaan 7 responden (87,5\%).
\end{abstract}

Kata Kunci : makanan sehat, pengetahuan ibu, bayi usia 0-12 bulan.

\section{PENDAHULUAN}

Peranan gizi terutama bagi manusia terutama ibu yang mempunyai anak balita sangatlah penting dan krusial. Gangguan pertumbuhan dan perkembangan bagi bayi dapat terjadi jika gizi tidak terpenuhi dan tidak diatasi sejak masih kecil sehingga akan mempengaruhi perkembangan saat dewasa [1]. World Health Organization (WHO) memberikan rekomendasi terkait pentingnya bayi berusia 6 bulan sampai dengan berusia 24 bulan perlu diberikan makanan pendamping air susu ibu yang fungsinya sebagai upaya pengoptimalan tumbuh kmbang bagi bayi. Pentingnya ibu mengetahui tentang produk pangan yang sehat untuk bayi yang berusia 0 sampai dengan 12 bulan yaitu agar status gizi bayi tersebut baik, sehingga tumbuh kembang bayi akan sesuai dengan umurnya [2]. Adapun yang di maksud dengan pangan sehat dan bergizi memiliki keterpenuhan keseimbangan gizi tubuh yang efeknya dapat berpengaruh terhadap kesehatan dan kondisi fisik serta mental [3].

Pada saat ini sering kita temui fakta dimasyarakat bahwa makanan pendamping susu ibu (MPASI) yang diberikan kepada bayi masih banyak yang tidak sesuai peruntukannya karena diberikan kepada bayi dengan usia di bawah enam bulan. Tentu saja hal ini sangat tidak tepat karena kondisi sistem pencernaan bayi belum sama dengan orang dewasa. Jenis makanan yang digunakan untuk pendamping air susu ibu ialah makanan yang secara kualitas dan dibuat dengan metode yang benar sehingga secara mutu pangan mempunyai sifat sehat dan higienis dan secara rasa, tekstur serta bahan dasarnya harus sesuai dengan kondisi sistem pencernaan bayi terutama usia 0 sampai 12 bulan. Jenis makanan sehat dan higienis bagi bayi atau sering disebut MPASI dilakukan secara bertahap sesuai sistem pencernaan bayi dengan tujuan agar tecipta kondisi sistem pencernaan yang adaptif dimulai dari pemberian makanan dengan tekstur cair, lunak, dan lumat padat [4].

Makanan sehat dan higienis yang diberikan pada bayi berupa MPASI harus terprogram dengan baik dan benar terutama pada aspek waktu pemberiannya dan kualitas bahan serta kehigienisannya agar risiko seperti terganggunya saluran pencernaan bayi serta alergi yang kemungkinan muncul pada bayi. Pemberian makanan sehat, bergizi, dan higienis secara tepat pada bayi apabila ditinjau dari aspek kesehatan dan faktor gizi akan merugikan bagi bayi jika 
diberikan pada usia yang tidak sesuai seperti usia masih kurang dari enam bulan karena konsumsi air susu ibu jelas akan mengalami penurunan dan juga berpotensi menimbulkan masalah pada sistem pencernaan. Pemberian makanan bagi bayi yang terlalu awal dapat menimbulkan gangguan pencernaan karena belum siapnya usus bayi untuk mencerna makanan secara baik, gangguan sistem pencernaan yang biasanya timbul adalah diare [5].

Badan Kesehatan Dunia atau sering disebut World Health Organization (WHO), dalam program WHO Global Strategy foe Feeding Infant and Young Children memberikan empat rekomendasi tentang pemberian makanan sehat dan higienis pendamping air susu ibu dengan empat syarat yang harus terpenuhi. Syarat pertama adalah tepat waktu (timely), syarat pertama ini mengharuskan makanan pendamping air susu ibu yang diberikan secara eksklusif saat kondisi bayi secara nutrisi dan gizi sudah tidak cukup jika hanya mengandalkan air susu ibu. Syarat yang kedua ialah adekuat yang berarti kandungan 17 iscui, kandungan protein, serta makronutrien yang digunakan untuk mencukupi kebutuhan makronutriean dimiliki oleh makanan pendamping air susu ibu serta harus sesuai dengan usia bayi. Syarat yang ketiga harus memiliki sifat aman. Safety food saat ini sudah menjadi syarat dan kebutuhan baik dalam hal pemilihan bahan, cara penyimpanan secara baik dan benar, serta cara pemberian secara baik dan benar seperti penggunaan peralatan makan yang sudah terstandar baik secara bahan maupun kebersihannya. Syarat yang terakhir yaitu harus memenuhi unsur properly fed atau pemberian makanan dilakukan secara benar. Dalam hal ini sinyal rasa lapar dan kenyang seorang bayi bisa dijadikan sebagai indikator dalam pemberian makanan pendamping air susu ibu sehingga secara aktif makanan dapat terkonsumsi dengan pemberian frekuensi makan dan metode pemberian yang benar [6].

Pemberian makanan bagi bayi harus di sesuaikan dengan berbagai hal yang menyangkut dengan kondisi bayi, seperti perkembangan alat pencernaan. Sehingga pemberian makanan yang tepat sangat direkomendasikan seperti faktor tekstur makanan deng anciri padat, cair, kental, semi padat dan sebagainya [7]. Status gizi dapat dijadikan salah satu indikator untuk melihat terpenuhi atau tidaknya gizi seseorang, hal itu tentu saja membutuhkan sebuah pengetahuan yang cukup terkait dengan status gizi serta kebutuhannya. Jenis makanan yang dikonsumsi terutama oleh bayi tentunya sangat bergantung pada ibu yang bertugas secara langsung memberikan asupan kepada bayi sehingga kemampuan dan pengetahuan seorang ibu terhadap gizi dan kebutuhan bayi menjadi sebuah kebutuhan yang sangat krusial untuk memastikan kondisi bayi tersebut mempunyai status gizi yang baik atau tidak. Hal lain yang harus diketahui oleh seorang ibu dalam pemenuhan nutrisi dan pangan yang sehat dan higienis adalah cara pemilihan makanan yang akan diberikan kepada bayi secara tepat, penentuan pola makan secara tepat terkait jumlah asupan yang diberikan, serta freuensi pemberian asupan makanan yang didasarkan pada kebutuhan makan bayi. Sehingga faktor umur, pendidikan, pekerjaan, dan pendapatan menjadi indiator tingkat pengetahuan ibu dalam hal pemberian asupan makanan yang sehat, higienis, dan tepat untuk bayi [8].

\section{METODE PENELITIAN}

Penelitian tentang gambaran pengetahuan ibu terkait pemberian makanan sehat dan bergizi bagi bayi usia 0 sampai 12 bulau ini menggunakan pendekatan Cross Sectional. Faktorfaktor risiko dicari korelasinya dengan cara mengumpulkan data sekaligus pada waktu dan saat tertentu [9]. Pendekatan deskriptif yang berbentuk survei digunakan dalam penelitian bertujuan untuk mendapatkan gambaran sebuah situasi atau fenomena yang ada dalam kehidupan masyarakat dan dapat digunakan sebagai alat bantu penilaian terhadap sebuah kondisi tertentu. Penyusunan perencanaan dan program terkait pengetahuan ibu terhadap MPASI bisa diguankan untuk mencari sebuah kebenaran dan untuk menyusun sebuah program perbaikan [10].

\section{HASIL DAN PEMBAHASAN}


Deskripsi tentang pandangan dan pengetahuan yang dimiliki oleh ibu dalam pemerian makanan sehat, bergizi, dan higiens kepada bayi usia 0 sampai 12 bulan dipengaruhi oleh beberapa faktor diantaranya adalah umur, tingkat pendidikan, dan pekerjaan ibu. Analisa secara univariat digunaan untuk melihat gambaran distribusi frekuensinya. Umur dibedakan menajdi tiga kategori kemudian dilihat persebaran frekuensinya serta persentase yang dihasilkan.

Tabel 1. Persebaran Frekuensi karakteristik responden berdasarkan umur responden

\begin{tabular}{llcc}
\hline No & Umur (tahun) & Jumlah & Persentase (dalam \%) \\
\hline 1 & $<20$ & 2 & $3,9 \%$ \\
2 & $20-35$ & 43 & $82,6 \%$ \\
3 & $>35$ & 7 & $13,5 \%$ \\
\hline Jumlah & & 52 & 100 \\
\hline
\end{tabular}

Sumber : Data primer

Tabel 1 menunjukkan rentang umur dikelompokkan menjadi tiga yaitu dibawah umur 20 tahun, 20 sampai 35 tahun, dan responden dengan umur lebih dari 35 tahun. Frekuensi paling rendah terlihat pada rentang usia kurang dari 20 tahun dengan jumlah responden sebanyak 2 yang memmiliki persentase sebesar 3,9\%. Untuk rentang usia 20-35 tahun terlihat memiliki frekuensi responden 43 dengan persentase $82,6 \%$, dan sisanya dengan persentase $13,5 \%$ diketahui terlihat pada rentang usia lebih dari 35 tahun dengan jumlah frekuensi 7. Hasil tersebut menunjukkan bahwa umur responden terkait pengetahuan ibu terhadap pemberian makanan ada bayi paling banyak pada rentang usia 20-30 tahun yang masih tergolong usia produktif secara reproduksi.

Tabel 2. Persebaran kelompok pendidikan Responden

\begin{tabular}{lccc}
\hline No. & TingkatPendidikan & Frekuensi & Persentase (\%) \\
\hline 1 & Sekolah Dasar & 22 & $42,3 \%$ \\
2 & Sekolah Menengah Pertama & 13 & $25,1 \%$ \\
3 & Sekolah Menengah Atas & 15 & $28,8 \%$ \\
4 & Perguruan Tinggi & 2 & $3,8 \%$ \\
\hline Total & & 52 & 100 \\
\hline
\end{tabular}

Sumber : Data primer

Kelompok pendidikan ditunjukkan distribusinya seperti pada Tabel 2 dengan hasil tingkat pendidikan terlihat dalam empat kategori pendidikan mulai dari sekolah dasar, sekolam menengah pertama, sekolah menengah atas, dan jenjang perguruan tinggi. Tingkat pendidikan pada jenjang perguruan tinggi atau lulusan universitas terlihat masih sangat rendah dilihat dari total responden. Untuk lulusan sekolah dasar terlihat paling dominan dimiliki oleh responden dengan frekuensi sebanyak 2 dan persentase sebesar $42 \%$. Sedangan lulusan sekolah menengah pertama dan sekolah menengah atas memiliki persentase yang hampir sama dengan tingkat persentase $25, \%$ dan $28,8 \%$.

Tabel 3. Persebaran Pekerjaan Responden

\begin{tabular}{llcc}
\hline No. & Jenis Pekerjaan & Frekuensi & Persentase (\%) \\
\hline 1 & Punya pekerjaan & 8 & $15,4 \%$ \\
2 & Tidak mempunyai Pekerjaan & 44 & $84,6 \%$ \\
\hline Jumlah & & 52 & $100 \%$ \\
\hline
\end{tabular}

Sumber : Data primer

Pekerjaan responden tergambar pada Tabel 3 di atas dengan hanya terdapat dua jenis kalsifikasi yaitu mempunyai pekerjaan dan tidak mempunyai pekerjaan. Responden ibu yang 
mempunyai bayi usia 0-12 bulan terlihat hanya $15,4 \%$ yang mempunyai pekerjaan, dan sisanya sebesar $84,6 \%$ tidak memiliki pekerjaan.

\section{KESIMPULAN}

Penelitian ini menghasilkan beberapa poin kesimpulan terkait dengan tingkat pengetahuan ibu terkait dengan pemberian makanan sehat pada bayi usia 0-12 bulan. Hasil tersebut menunjukkan bahwa umur responden terkait pengetahuan ibu terhadap pemberian makanan pada bayi paling banyak pada rentang usia 20-30 tahun yang masih tergolong usia produktif secara reproduksi. Tingkat pendidikan pada jenjang perguruan tinggi atau lulusan universitas terlihat masih sangat rendah dilihat dari total responden. Untuk lulusan sekolah dasar terlihat paling dominan dimiliki oleh responden dengan frekuensi sebanyak 2 dan persentase sebesar $42 \%$. Hal tersebut menunjukkan bahwa responden memiliki tingkat pendidikan yang rendah. Untuk karakteristik berdasarkan jenis pekerjaan terihat bahwa responden sebagian besar tidak bekerja dengan persentase mencapai 84,6 persen dengan jumlah 44 responden.

\section{SARAN}

Diharapkan semua pihak terkait terkait dapat memberikan pendidikan kesehatan untuk ibu tentang makanan sehat agar dapat menambah pengetahuan bagi ibu khususnya yang memiliki anak dengan kebutuhan makanan sehat dan bergizi, misalnya cara dan metode terkait makanan, bahan, waktu, dan hal lainnya yang berkaitan dengan nutrisi dan status gizi bayi.

\section{DAFTAR PUSTAKA}

[1] Goi, 2013, Gizi Bayi, Jurnal Jurusan Gizi Poltekes Kemenkes Gorontal, Politeknik Kesehatan Kemenkes Gorontalo.

[2] Kusuma, 2012, Nutrisi dan Makanan Sehat Bayi, Http://www.onesearch.ac.id [diakses tanggal 06 Desember 2019].

[3] Prasetyono, 2009, Makanan Sehat Bayi. Http://www.media.neliti.com [diakses 27 Juli 2020].

[4] Bennu dkk, 2012, Hubungan Pemberian Makanan Pendamping ASI (MP_ASI) dengan Status Gizi Bayi 6- 12 Bulan di Posyandu Kurusumange Kecamatan Tanralili Kabupaten Maros. Poltekkes Kesehatan Kemenkes Makassar. Volume 1 nomor 4 Tahun 2012.

[5] Febri, 2009, Makanan Pendamping ASI, http://www.herdaily.com/blogimg/parenting/babyeating.jpg. [diakses tanggal 19 Mei 2021].

[6] WHO, 2003, Global Strategy for Feeding Infant and Young Children https://toolkits.knowledgesuccess.org/toolkits/breastfeeding-advocacytoolkit/global-strategy-infant-and-young-child-feeding [ Diakses tanggal 20 Mei 2021].

[7] Marimbi, 2010, Tumbuh Kembang, Status Gizi dan Imunisasi Dasar pada Balita. Yogyakarta: Nuha Medika.

[8] Arista, 2009, Faktor yang mempengaruhi Status Gizi, http://www.ners.fkep.unand.ac.id [diakses tanggal 26 Juli 2020].

[9] Ariana, 2014, Ruang dan JenisPenelitian, http://www.journaluntad.id [diakses Tanggal 28 Juli 2020].

[10] Notoatmodjo, 2005, Hubungan Pengetahuan Dengan Perilaku. Http://www.journalunitad.com [diakses Tanggal 27 Juni 2020]. 